\title{
Aerobic Degradation of Benzene by Escherichia spp. from Petroleum-contaminated Sites in Kolkata, West Bengal, India
}

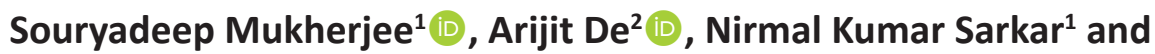 \\ Nimai Chandra Saha ${ }^{3 *}$ (iD)
}

${ }^{1}$ Department of Life Sciences, Presidency University, 86/1, College Street, Kolkata, West Bengal - 700073 , India. ${ }^{2}$ Department of Zoology, Vidyasagar College, Block CL, Plot 3-8 \& 44-50, Sector II, Salt Lake, Kolkata, West Bengal - 700 091, India. ${ }^{3}$ Fishery and Ecotoxicology Research Laboratory (Vice-Chancellor's Research Group), Department of Zoology, The University of Burdwan, Burdwan - 713 104, West Bengal, India.

\begin{abstract}
Benzene is an omnipresent aromatic hydrocarbon of the environment and the pollution caused by it is a matter of great public concern. The study was designed to isolate, characterize and identify aerobic bacterial strains capable of benzene degradation from petroleum-contaminated soils of Kolkata, India. Three strains, designated as MKB1b, MKB2a and MKB2d were found to be able to degrade benzene, as the only source of carbon and energy. All the isolated strains had an optimal growth $\mathrm{pH}$ of 8.0, and grew best at $37^{\circ} \mathrm{C}$ to $40^{\circ} \mathrm{C}$. Based on their molecular (16S rDNA sequence) characterization, all of the three bacterial strains were phylogenetically similar to the genus Escherichia. Strains MKB2a and MKB2d were identified as Escherichia coli, whereas Strain MKB1b was identified as Escherichia fergusonii; all three sequences were submitted to GenBank bearing accession numbers MK970556, MK970574, MK970557 respectively. This study is the first evidence of isolation, characterization and identification of aerobic benzene-degrading Escherichia spp. from petroleum-contaminated sites of an urban landscape in India. All of these isolated strains may be considered as potent candidates for the bioremediation of urban environment polluted with petroleum products.
\end{abstract}

Keywords: Escherichia, aerobic biodegradation, aromatic hydrocarbon, petroleum-contaminated soil.

*Correspondence: ncsvcbu@gmail.com; +918617482954

(Received: 08 June 2019; accepted: 02 November 2019)

Citation: Souryadeep Mukherjee, Arijit De, Nirmal Kumar Sarkar and Nimai Chandra Saha, Aerobic Degradation of Benzene by Escherichia spp. from Petroleum-contaminated Sites in Kolkata, West Bengal, India, J Pure Appl Microbiol., 2019; 13(4):23532362. https://doi.org/10.22207/JPAM.13.4.51

(C) The Author(s) 2019. Open Access. This article is distributed under the terms of the Creative Commons Attribution 4.0 International License which permits unrestricted use, sharing, distribution, and reproduction in any medium, provided you give appropriate credit to the original author(s) and the source, provide a link to the Creative Commons license, and indicate if changes were made. 


\section{INTRODUCTION}

Benzene (formula $\mathrm{C}_{6} \mathrm{H}_{6}, \mathrm{MW} 78$ ); a hydrophobic, volatile, colourless, highly flammable, aromatic hydrocarbon; is a preeminent component of crude as well as refined petroleum and most (98\%) of it is commercially used as a resource for petrochemical and chemical industries, petroleum refining industries, and for manufacturing synthetic rubbers, tyres, gums, lubricants, pharmaceuticals, pesticides and other agricultural chemicals, plastics, dyes, polymers, resins, synthetic fibres and consumer products such as marking pens, glues, adhesives, thinners, shoe-polish, perfumes, after shave lotions and paints ${ }^{1,2}$. Benzene is a major component of petrol, diesel, gasoline and other automobile fuels. After glucosyl residues, benzene ring is globally regarded as the most extensively distributed chemical structure ${ }^{3}$.

Benzene enters into the human systems by cutaneous exposure or by inhalation ${ }^{4}$. The human population is exposed to benzene because of its presence in the proximity of benzene utilizing industries and gas stations, and in areas of high vehicular traffic. Cigarette smokers are also directly exposed to benzene ${ }^{5,6}$. The relation of benzene exposure and the concomitant risk of cancer formation in human tissues and organs have been well-documented ${ }^{7}$. The toxic effects of benzene have also been related to developing hematopoietic disorders like acute myeloid leukemia, lymphocytic leukemia and non-Hodgkin's lymphoma ${ }^{8,9}$, primarily caused by chromosomal alterations attributing to malignant transformation of the genome $\mathrm{e}^{9,10}$. It has been also suggested that a number of epigenetic alterations, mostly DNA methylation, may also play a role in formation of tumor ${ }^{12}$.

Remediation of groundwater contaminated with benzene and other aromatic hydrocarbons has been proven to be an arduous task, due to the fact that these compounds are recalcitrant, water-insoluble and have the ability of diffusing rapidly once they are introduced into the aquifer system ${ }^{13}$. Mineralization of benzene has been a matter of priority for nearly three decades and microbial bioremediation of the same has been reported under aerobic conditions by genera, Nitrosomonas ${ }^{14}$, Pseudomonas ${ }^{15,16,17}$, Acinetobacter $^{18}$, Lysinibacillus ${ }^{19}$ as well as in the presence of other electron acceptors by genera,
Geobacter $^{20}$, Dechloromonas ${ }^{21}$, Desulfobacterium ${ }^{22}$. Studies on bacterial mineralization of aromatic compounds like benzene have been focused, and microorganisms capable of benzene biodegradation under aerobic conditions have been isolated from industrial areas, and areas adjoining oil fields and oil-refineries ${ }^{22-24}$. Exploration of aromatic hydrocarbon degrading microbial diversity in and around urban habitats in India as potential sources of bioremediation is severely lacking.

This study has been designed to explore the microbial diversity capable of benzene degradation, in pure culture, as the sole carbon and energy source in petroleum-contaminated sites located in Kolkata, India. Characterization of the microbes as well as assessment of environmental conditions favouring bioremediation of benzene were also studied.

\section{MATERIALS AND METHODS \\ Sample collection}

Six gas stations situated in Kolkata, West Bengal, India $\left(22.57^{\circ} \mathrm{N}, 88.36^{\circ} \mathrm{E}\right)$ were used as sites for collection of petroleum-mixed soil samples. Around $100 \mathrm{gm}$ of soil from each site was collected in labeled, sterile glass containers from a depth of around $10 \mathrm{~cm}$ from top soil-surface and were aseptically transferred to the laboratory for further analysis. Microbiological investigations of all the samples were initiated strictly within 12 hours of collection.

\section{Reagents and Culture Media}

Microbial culture media mentioned in the experiments were procured from HIMEDIA (India), whereas, aromatic hydrocarbons were procured from Sigma Aldrich (USA)and were of HPLC grades. Pure cultures were obtained, and growth experiments were carried out with sterile nutrient agar and Luria agar medium used after sterilization at $120^{\circ} \mathrm{C}$ temperature and 105 $\mathrm{K}$ Pa pressure, for 15 minutes. Sterile Minimal salt media (MSM), having the composition of $\mathrm{Na}_{2} \mathrm{HPO}_{4}, 3.61 \mathrm{~g}$; $\left(\mathrm{NH}_{4}\right)_{2} \mathrm{SO}_{4}, 2 \mathrm{~g} ; \mathrm{KH}_{2} \mathrm{PO}_{4}, 1.75 \mathrm{~g}$; $\mathrm{MgSO}_{4} \cdot 7 \mathrm{H}_{2} \mathrm{O}, 0.2 \mathrm{~g} ; \mathrm{CaCl}_{2} \cdot \mathrm{H}_{2} \mathrm{O}, 50 \mathrm{mg} ; \mathrm{FeSO}_{4} \cdot 7 \mathrm{H}_{2} \mathrm{O}$, $1 \mathrm{mg}$; $\mathrm{ZnSO}_{4}$. $7 \mathrm{H}_{2} \mathrm{O}, 70 \mu \mathrm{g}$; $\mathrm{CuSO}_{4} \cdot 5 \mathrm{H}_{2} \mathrm{O}, 50 \mu \mathrm{g}$; $\mathrm{H}_{3} \mathrm{BO}_{3}, 10 \mu \mathrm{g} ; \mathrm{MgSO}_{4} .5 \mathrm{H}_{2} \mathrm{O}, 10 \mu \mathrm{g} ; \mathrm{MoO}_{3}, 10 \mu \mathrm{g}$; $\mathrm{pH}$ 7.0, was employed as a source of essential macro and micro-nutrients for culture of bacterial strains with aromatic hydrocarbons. Benzene was added to MSM, as and when required, after filter 
sterilization with $0.22 \mu$ bacteriological filter.

Isolation, purification and characterization of benzene-degrading strains

From each labeled sample, $5 \mathrm{gm}$ of soil was inoculated in MSM (1L), supplemented with $(1 \% \mathrm{v} / \mathrm{v}) \mathrm{n}$-hexadecane and incubated at $37^{\circ} \mathrm{C}$ temperature, under shaking condition (120 rpm) until the occurrence of visible growth. Inoculum from this MSM-n-hexadecane culture $\left(10^{-4}\right.$ to $10^{-8}$ dilutions) were then spread in MSM agar $(2 \% \mathrm{w} / \mathrm{v})$, supplemented with $(2 \% \mathrm{v} / \mathrm{v})$ $n$-hexadecane and once again incubated at $37^{\circ} \mathrm{C}$ temperature. After 72 hours of incubation, the bacterial isolate / colony was checked for purity by photomicrography with a Zeiss Axio Scope A1 Microscope, as well as spreading them on sterile Luria Agar plates. All the isolated and purified bacterial strains were stored both as nutrient agar stab and $15 \%$ glycerol stock at $4^{\circ} \mathrm{C}$ and $-80^{\circ} \mathrm{C}$, respectively. Strains capable of utilizing $\mathrm{n}$-hexadecane as the sole carbon source were then screened for their aerobic benzene degradation ability by the following method. Each of the strains was inoculated into $15 \mathrm{ml}$ MSM supplemented with benzene $(1 \% \mathrm{v} / \mathrm{v})$, and incubated at $37^{\circ} \mathrm{C}$, at $120 \mathrm{rpm}$ in an orbital shaker for 7 days. Cultures with visible growth were again spread onto MSM agar plates supplemented with benzene $(1 \% \mathrm{v} / \mathrm{v})$ in serially diluted suspensions ( $10^{-4}$ to $10^{-8}$ dilutions). Well-isolated colonies were chosen from these plates based on their cultural characteristics like, colour of surface, shape, margin, texture and elevation using single colony isolation procedure. An array of biochemical tests were performed to characterize the strains according to Bergey's Manual of Systematic Bacteriology ${ }^{26}$.

\section{Antibiogram test}

Antibiogram or antibiotic susceptibility of the isolated strains was executed by the disk diffusion method ${ }^{27}$ on Mueller-Hinton agar (MHA) plates with antimicrobial susceptibility test disks (HiMedia) of 10 antimicrobial drugs. Bacterial isolates were analyzed for susceptibility, reduced susceptibility, or resistance towards an antimicrobial drug based on the inhibitory zone diameter matching the manufacturer's interpretive table's criteria, following the recommendations of the National Committee for Clinical Laboratory Standards ${ }^{28}$. Escherichia coli ATCC 25922 strain was used for quality control (qc).

\section{Measurement of temperature and $\mathrm{pH}$ optima}

Temperature and $\mathrm{pH}$ optima of the strains were tested to evaluate the culture conditions needed for most effective aerobic bioremediation of benzene. For testing the $\mathrm{pH}$ optima, each isolated strain was grown in six tubes each containing $5 \mathrm{ml}$ of sterile nutrient broths (having $\mathrm{pH}$ varying from 2 to 9) and $15 \times 10^{7} \mathrm{ml}^{-1}$ cells from overnight culture were added and incubated at $37^{\circ} \mathrm{C}$ temperature, at $120 \mathrm{rpm}$ in an orbital shaker. Temperature optima of each isolates were evaluated by inoculating $15 \times 10^{7} \mathrm{ml}^{-1}$ cells from overnight cultures to six tubes each containing 5 $\mathrm{ml}$ of sterile nutrient broths $(\mathrm{pH} 7)$ and incubated at temperatures of $25^{\circ}, 30^{\circ}, 35^{\circ}, 37^{\circ}, 40^{\circ}$ and $45^{\circ} \mathrm{C}$ in an orbital shaker at $120 \mathrm{rpm}$ for 12 hours.

In both experiments, cell density of each tube, after 12 hours of incubation, was measured spectrophotometrically at $660 \mathrm{~nm}$ by a SYSTRONICS 2202 Double Beam Spectrophotometer.

Molecular identification of the isolated strains Genomic DNA of the strains were isolated as described by Sambrook et. al., $2001{ }^{29}$ with the following modifications. Cells were harvested from $1.5 \mathrm{ml}$ of the overnight Luria Broth culture and resuspended in $567 \mu \mathrm{l}$ TE Buffer $(10 \mathrm{mM}$ Tris, $1 \mathrm{mM}$ EDTA), pH 8.0. After addition of $30 \mu \mathrm{l} 10 \% \mathrm{SDS}$ and incubation for 1 hour at $37^{\circ} \mathrm{C}, 100 \mu \mathrm{l}$ of $5 \mathrm{M} \mathrm{NaCl}$ was added. After addition of $80 \mu$ l of cetyltrimethyl ammonium bromide (CTAB)/ $\mathrm{NaCl}$, and after mixing vigorously, the mixture was incubated at $65^{\circ} \mathrm{C}$ for 10 minutes. After extraction with equal volume of chloroform: isoamyl alcohol (24:1) and another extraction with equal volume of phenol: chloroform: isoamyl alcohol, DNA was precipitated with isopropyl alcohol, washed with chilled $70 \%$ ethanol, dried and dissolved in appropriate volume of TE buffer, pH 8.0.

The 16S rRNA gene was amplified by PCR (Perkin-Elmer Applied Biosystems, Weiterstadt, Germany) reaction mixtures, with template DNA $(1 \mu \mathrm{g})$; forward primer $27 \mathrm{f}$ (5'-AGAGTTTGATCMTGGCTCAG-3'), reverse primer 1492r (5'-GGTTACCTTGTTACGACTT-3'), both $1 \mu \mathrm{l}$ from $10 \mathrm{pmol} / \mu \mathrm{l}$ working solution; $25 \mu \mathrm{l}$ PCR Master Mix (Thermo Scientific, USA); volume made up to $50 \mu$ l with sterile nuclease-free water. PCR products were purified by GeneJET PCR Purification Kit (Thermo Scientific, USA), electrophoresed in $1.5 \%(\mathrm{w} / \mathrm{v})$ agarose gel and were visualized over a 
transilluminator after ethidium bromide staining. Sequencing of the purified amplicons were done by a paid sequencing facility from Xceleris (Ahmedabad, India).

\section{Phylogenetic analysis of the strains}

For the identification and phylogenetic analyses of the strains the sequences obtained were queried in BLASTn software and top ten hits were selected for each strain for further downstream tests. CLUSTALW was used to align these sequences and for annotation purposes. The results were then subjected to phylogenetic analysis using Maximum Likelihood method and Jukes-Cantor model ${ }^{30}$. Initial trees for the heuristic search were obtained with the NeighborJoining method forming a pairwise distance matrix predicted using the Maximum Composite Likelihood (MCL) approach ${ }^{31}$. Branch lengths of the tree is determined by the number of base substitutions per site. All in silico-analyses were done on MEGA X software ${ }^{32}$. The final sequences were then subjected to test for potential chimeras using DECIPHER chimera check software ${ }^{33}$ and were then submitted to GenBank.

\section{Benzene biodegradation assay}

Aerobic degradation of benzene by the isolated bacterial strains along with their timecourse study were done as according to Mukherjee et. al., $2010^{34}$ with following modifications. In sterile $15 \mathrm{ml}$ Teflon-lined capped tubes, inocula $\left(15 \times 10^{7}\right.$ cells $\mathrm{ml}^{-1}$ from a 12 hour old culture, washed in sterile PBS, pH 7.0) were added into MSM overlaid with HPLC grade benzene $(100 \mu$ Mole, added from filter-sterilized stock solutions) ensuring enough head-space for the maintenance of aerobic conditions, and incubated at $37^{\circ} \mathrm{C}$ temperature, $120 \mathrm{rpm}$ in an orbital shaker-incubator. MSM with $100 \mu \mathrm{M}$ benzene supplemented with heatkilled (by 15 minutes incubation at $70^{\circ} \mathrm{C}$ ) cells of each strains and $15 \times 10^{7}$ cells $\mathrm{ml}^{-1}$ of each strain in MSM, not supplemented with benzene were used at negative controls (Control 1 and Control 2 respectively). A week-long experiment was set in the manner and cell numbers were determined at a gap of 24 hours by centrifugation of the cultures at $8000 \mathrm{rpm}$ for $10 \mathrm{~min}$, washing cell pellets twice with sterile PBS, resuspension in sterile PBS and direct microscopic count under oil immersion.

After each 24 hours of biodegradation, samples of each tube were extracted with 10 $\mathrm{ml}$ of HPLC grade chloroform. Concentrations of benzene in each culture was evaluated by high performance liquid chromatography (HPLC) as described previously ${ }^{21}$, using a Waters model 600 HPLC system equipped with Waters 2996 Photodiode Array Detector (Milford, MA, USA), at $254 \mathrm{~nm}$. HPLC analyses were done isocratically, at room temperature with a mobile phase of methanol: water 60:40 (v/v) at a flow rate of $1 \mathrm{~mL}$ $\mathrm{min}^{-1}$, by an analytical column (Symmetry- $\mathrm{C}_{18} 5 \mu \mathrm{m}$, $4.6 \mathrm{~mm}$ i.d. X $25 \mathrm{~cm}$ long, Waters, USA).

\section{Statistical analysis of data}

Data values are expressed as [mean values \pm standard deviation (S.D.)] from at least three replicates of experiments. Differences among sets were considered significant at $(P \geq$ 0.05) level. SPSS 17.0 (SPSS Inc., Chicago, USA) was used to implement statistical analyses and to compare means by Student's t-test.

\section{RESULTS}

Identification of strains and determination of $\mathrm{pH}$ and temperature optima

Three bacterial strains were selected for further studies, among 16 isolates capable of utilizing $n$-hexadecane as sole carbon and energy source, due to their ability of growing in MSM, supplemented with benzene. Results of morphological and biochemical characterization of these three Gram-negative, rod-shaped facultative anaerobic bacterial strains are enlisted in Table 1. MKB1b was found to be the only non-motile bacteria among the three. The three strains exhibited nearly similar biochemical characteristics but differed in their ability in acid production from lactose and sucrose.

The three strains were identified and they all belong to the genus Escherichia. Strain MKB2a and MKB2d were identified as E. coli, whereas Strain MKB1b was identified as E. fergusonii. 16S Ribosomal DNA sequences of all three strains were submitted to the GenBank bearing accession numbers MK970556, MK970574, MK970557 respectively. The phylogenetic tree constructed is depicted in Fig. 1. The tree shows the phylogenetic position of the three strains when compared with their nearest neighbours from BLASTn hits. The three strains belong to the same lineage but differs in the strain level as elucidated by the difference in the branch lengths. 
Table 1. Morphological and biochemical characters of the three bacterial isolates obtained from petroleum contaminated soil samples in Kolkata.

\begin{tabular}{|c|c|c|c|}
\hline $\begin{array}{l}\text { Morphological } \\
\text { Characteristics } \\
\text { a. Colony character }\end{array}$ & $\begin{array}{l}\text { Translucent with } \\
\text { Opaque centre, } \\
\text { greyish-white, smooth }\end{array}$ & $\begin{array}{c}\text { Translucent with } \\
\text { opaque centre, } \\
\text { off-white, smooth, thick }\end{array}$ & $\begin{array}{l}\text { MKB2d } \\
\text { Translucent with } \\
\text { opaque centre, } \\
\text { colourless, smooth }\end{array}$ \\
\hline b. Cell morphology & Rod-shaped & Rod-shaped & Rod-shaped \\
\hline c. Gram character & - & - & - \\
\hline d. Motility at $37^{\circ} \mathrm{C}$ & + & + & + \\
\hline $\begin{array}{l}\text { e. Spore formation } \\
\text { Biochemical } \\
\text { characteristics }\end{array}$ & - & - & - \\
\hline a. Urease & - & - & - \\
\hline b. DNase & - & - & - \\
\hline c. Oxidase & - & - & - \\
\hline d. Voges-Proskauer & - & - & - \\
\hline e. Gelatinase & - & - & - \\
\hline f. Methyl Red & + & + & + \\
\hline g. Indole & + & + & + \\
\hline h. $\mathrm{H}_{2} \mathrm{~S}$ production & - & - & - \\
\hline i. Citrate & - & - & - \\
\hline $\begin{array}{l}\text { j. Nitrate reduction } \\
\text { Acid formation from }\end{array}$ & + & + & + \\
\hline a. Lactose & - & + & + \\
\hline b. Maltose & + & + & + \\
\hline c. Glucose & + & + & + \\
\hline d. Mannitol & + & + & + \\
\hline e. Sucrose & - & - & + \\
\hline
\end{tabular}

Among the ten antibiotics tested; MKB1b, MKB2a and MKB2d showed resistance to 5,3 and 3 antibiotics respectively. All the strains showed resistance to Ampicillin $(10 \mu \mathrm{g})$, Erythromycin $(15 \mu \mathrm{g})$ and Vancomycin $(30 \mu \mathrm{g})$ (Table 2).

Strains MKB1b, MKB2a and MKB2d showed considerable growth within a range of $\mathrm{pH}$ 6.0 to 8.0 , having the maximum growth at $\mathrm{pH} 8.0$ (Fig. 2). All the strains exhibited better growth at an alkaline environment ( $\mathrm{pH} 9.0)$ than in an acidic one ( $\mathrm{pH} 4.0$ and 2.0). All the three strains were able to grow at the range of temperature tested, from $25^{\circ} \mathrm{C}$ to $45^{\circ} \mathrm{C}$. Optimum temperature for growth of the strains MKB1b and MKB2a was found to be at $37^{\circ} \mathrm{C}$, whereas, MKB2d showed nearly equal growth pattern at both $37^{\circ} \mathrm{C}$ and $40^{\circ} \mathrm{C}$ (Fig. 3).

\section{Aerobic biodegradation of Benzene}

Aerobic benzene biodegradation of strains MKB1b, MKB2a and MKB2d were carried out at their optimum $\mathrm{pH}$ and temperature with $100 \mu \mathrm{M}$ benzene and $15 \times 10^{7}$ cells $\mathrm{ml}^{-1}$ respectively. Depletion of benzene in the heat-killed inoculum (Control 1) was negligible ( $P<0.01$ ), and 89.66 $\pm 0.87 \mu \mathrm{M}$ benzene remained undegraded in the culture, whereas, cell number $\left(10.57 \times 10^{7} \pm 1.89\right.$

Table 2. Antibiogram test results of the isolated Escherichia strains from petroleum contaminated soil samples in Kolkata, using 10 antimicrobial drugs.

\begin{tabular}{ccc}
\hline & Sensitive & Resistant \\
\hline MKB1b & S, Of, K, C, G & A, Co, E, T, Va, \\
MKB2a & S, Of, K, T, C, Co, G & A, E, Va \\
MKB2d & S, Of, K, T, C, Co, G & A, E, Va \\
\hline
\end{tabular}

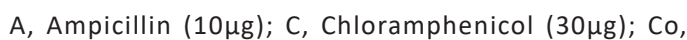

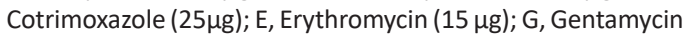
$(10 \mu \mathrm{g}) ; \mathrm{K}$, Kanamycin $(30 \mu \mathrm{g}) ;$ Of, Ofloxacin $(5 \mu \mathrm{g}) ; \mathrm{S}$,

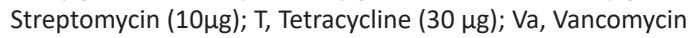
(30 $\mu \mathrm{g})$ 
$\mathrm{ml}^{-1}$ ) in the culture without added benzene did not vary much $(P<0.01)$ over an incubation period of 7 days (Fig. 4). Strain MKB2a exhibited the most efficient benzene degrading ability of the three, and could degrade benzene up to a final concentration of $28.48 \pm 2.17 \mu \mathrm{M}$ after 7 days. In case of the other two strains, $44.82 \pm 1.84 \mu \mathrm{M}$ and $39.55 \pm 1.87 \mu \mathrm{M}$ of benzene remained unexhausted in the cultures of MKB1b and MKB2d respectively. Bacterial cell density in media, containing benzene as sole carbon and energy source, increased to values of $(52.58 \pm 0.98),(64.11 \pm 1.12)$ and $(58.78$ $\pm 1.88) \times 10^{7}$ cells $\mathrm{ml}^{-1}$ from an initial density of $15 \times 10^{7}$ cells $\mathrm{ml}^{-1}$ in cultures containing MKB1b, MKB2a, and MKB2d respectively.

\section{DISCUSSION}

E. coli is the most abundant and successful bacterial flora in the gut ecosystem of warmblooded animals and is a pathogen of the enteric, urinary, pulmonary, and nervous systems also ${ }^{35}$. However, this commensal can also thrive in extracorporeal environment ${ }^{36}$ and has the ability to withstand ample range of physico-chemical

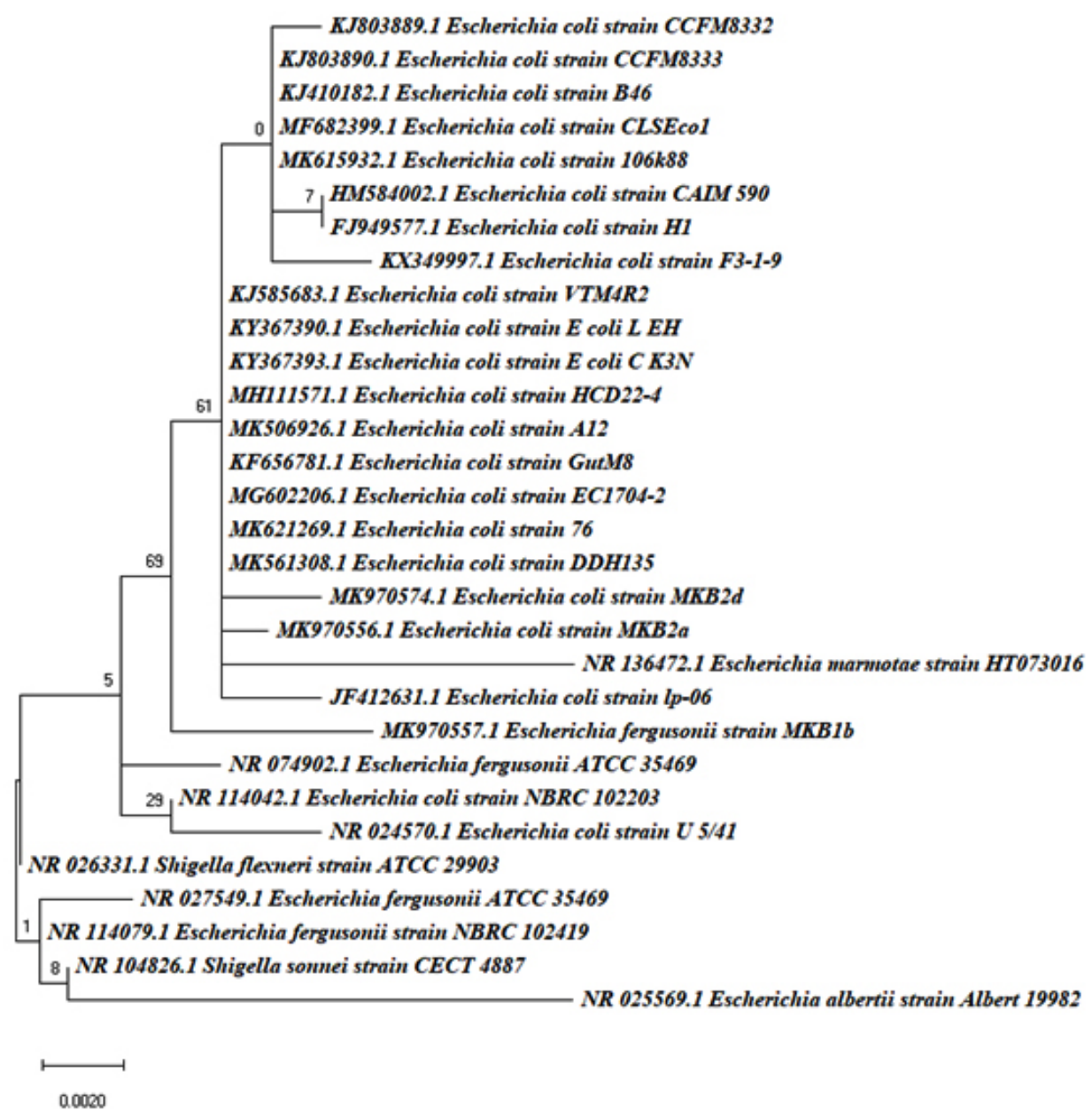

Fig. 1. The phylogenetic tree was constructed by using the Maximum Likelihood method and Jukes-Cantor model. The tree with the highest log likelihood (-1546.11) is shown. Initial tree(s) for the heuristic search were obtained by applying the Neighbor-Joining method to a matrix of pairwise distances estimated using the Maximum Composite Likelihood (MCL) approach. The tree is drawn to scale, with branch lengths measured in the number of substitutions per site. This analysis involved 30 nucleotide sequences. There was a total of 875 positions in the final dataset. Evolutionary analyses were conducted in MEGA X. 
conditions, enabling it as a successful survivor in various environments over long periods of time $^{37}$. E. coli, can also survive and replicate in environments having an abundance of aromatic hydrocarbons; and can actually utilize the aromatic compounds as sources of carbon. On

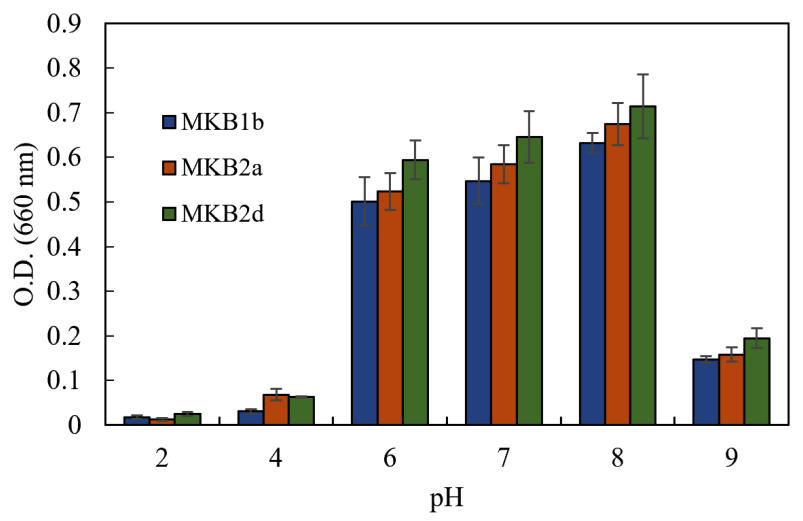

Fig. 2. Growth of MKB1b, MKB2a and MKB2d in enrichment media at a pH range of 2 to 9 , after 12 hours of incubation at $37^{\circ} \mathrm{C}, 120 \mathrm{rpm}$.

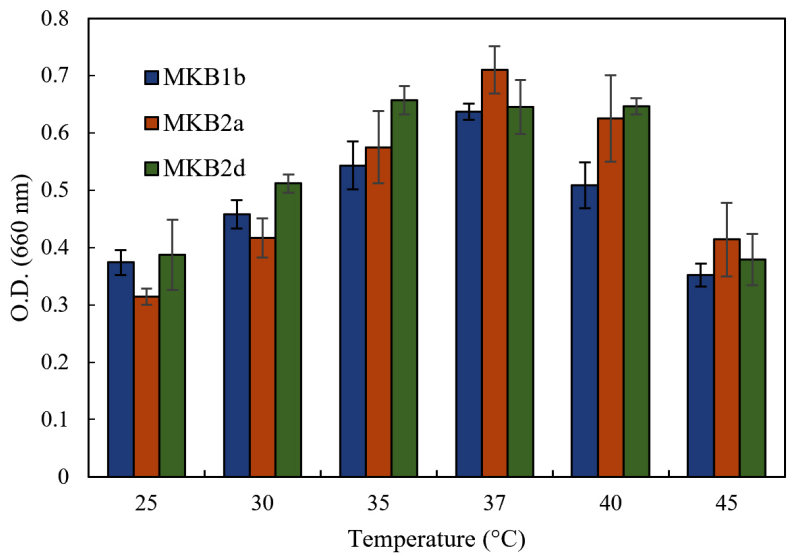

Fig. 3. Growth of MKB1b, MKB2a and MKB2d in enrichment media at six temperatures within a range of $25^{\circ}$ to $45^{\circ} \mathrm{C}$, after 12 hours of incubation at $120 \mathrm{rpm}$

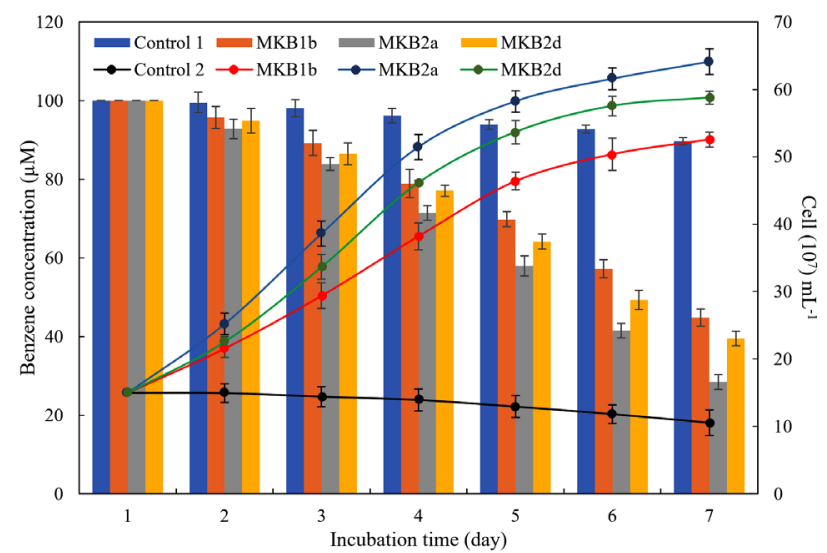

Fig. 4. Growth curve and aerobic benzene degradation by MKB1b, MKB2a and MKB2d over a time period of 7 days. Bars and broken lines represent benzene concentration $(\mu \mathrm{M})$ in culture media and cell number $\left(\times 10^{7} \mathrm{ml}^{-1}\right)$ respectively. MSM added with benzene, inoculated with heat-killed cells and MSM with live cells, but with no added benzene are termed as Control 1 and Control 2 respectively. $[n=3, P \leq 0.05]$ 
the other hand, E. fergusonii has previously been documented to be able to degrade herbicides like, atrazine and diuron ${ }^{38}$ and diesel oil ${ }^{39,40}$.

This is a novel report of aerobic degradation of benzene by $E$. coli and $E$. fergusonii strains, isolated from petroleum-contaminated sites in the densely populated city of Kolkata, West Bengal, India. Earlier reports of bacterial species capable of mineralizing benzene and other aromatic hydrocarbons, had been concentrated around oil-field and oil-refineries only ${ }^{41-43}$. In pure culture, benzene biodegradation have been reported by a number of aerobic bacterial genera like, Geobacter ${ }^{44}$, Desulfobacterium ${ }^{45}$, Dechloromonas ${ }^{21}$ and Bacillus ${ }^{46}$; and anaerobic genera like, Nitrosomonas ${ }^{14}$, Pseudomonas ${ }^{16,17}$ and Acinetobacter ${ }^{18}$. In genus Escherichia, degradation of aromatic compounds like, hydroxyphenyl acetic acid, 3-hydroxyphenylpropionic acid; 3-hydroxycinnamic acid; and phenylacetic acid have been comprehensively studied ${ }^{47}$.

$E$. coli and $E$. fergusonii strains described in this study could degrade benzene as the sole carbon and energy source, in pure culture, up to a concentration of $71.52 \mu \mathrm{M}$ over a period of 7 days under aerobic conditions. In enrichment studies, all of the strains showed maximum proliferation at a temperature range of $37^{\circ} \mathrm{C}$ to $40^{\circ} \mathrm{C}$ and in alkaline $\mathrm{pH} 8.0$, making them potential bio-remediators of benzene-contaminated soils. Further insights on the mechanism of benzene mineralization, characterization of the genes involved as well as extensive investigations of urban microbial diversity are warranted to utilize as proficient candidates against aromatic hydrocarbon pollution.

\section{ACKNOWLEDGEMENT}

Infrastructural assistance obtained from Central Instrument Centre $(\mathrm{CIC})$ and $\mathrm{CIC}$ Imaging, Department of Life Sciences, Presidency University, Kolkata and the Department of Zoology, University of Burdwan is gratefully acknowledged. This communication contains data from a thesis to be submitted for the partial fulfilment of the Degree of Doctor of Philosophy in the Department of Zoology, The University of Burdwan, West Bengal, India.

\section{CONFLICTS OF INTEREST}

The authors confirm that there is no conflict of interest.

\section{AUTHOR'S CONTRIBUTION}

SM performed all the laboratory experiments, analysis of data and manuscript writing. AD was involved in field sampling and molecular phylogenetic studies. NKS and NCS conceived the research idea, oversaw experiments and finalized the manuscript.

\section{FUNDING}

The work has been partially funded by the Faculty Research and Development Fund (FRPDF), Presidency University, Kolkata, allocated to SM.

\section{DATA AVAILABILITY}

Data supporting the present study are available from the first and corresponding authors upon justifiable request. 16S rDNA sequences of the bacterial strains are accessible at GenBank (https://www.ncbi.nlm.nih.gov/genbank/) bearing accession numbers MK970556, MK970574 and MK970557.

\section{ETHICS STATEMENT}

This article does not contain any studies with human participants or animals performed by any of the authors.

\section{REFERENCES}

1. Jindrova A, Chocova M, Demnerova K, Brenner V. Bacterial aerobic degradation of benzene, toluene, ehtylbenzene, and xylene. Folia Microbiologica, 2002; 47: 83-93. https://doi.org/10.1007/BF02817664

2. Smith MT. Advances in Understanding Benzene Health Effects and Susceptibility. Annual Review of Public Health, 2010; 31: 133-148. https://doi.org/10.1146/ annurev.publhealth.012809.103646

3. Song J, Zhao Q, Guo J, Yan N, Chen H, Sheng F, Lin $Y$, An D. The microbial community responsible for dechlorination and benzene ring opening during anaerobic degradation of 2,4,6 trichlorophenol. Science of The Total Environment, 2019; 651: 13681376. https://doi.org/10.1016/j.scitotenv.2018.09.300

4. Brandt L. Exposure to organic solvents and risk of haematological malignancies. Leuk. Res., 1992; 16: 6770. https://doi.org/10.1016/0145-2126(92)90103-E

5. Ray MR, Roychoudhury S, Mukherjee S, Lahiri T. Occupational benzene exposure from vehicular sources in India and its effect on hematology, lymphocyte subsets and platelet P-selectin expression. Toxicology and Industrial Health, 2007; 23: 167-175. 
https://doi.org/10.1177/0748233707080907

6. Khalade A, Jaakkola MS, Pukkala E, Jaakkola JJK. Exposure to benzene at work and the risk of leukemia: A systematic review and meta-analysis. Environmental Health: A Global Access Science Source, 2010; 9: 1-8. https://doi.org/10.1186/1476-069X-9-31

7. Falzone L, Marconi A, Loreto C, Franco S, Spandidos DA, Libra M. Occupational exposure to carcinogens: Benzene, pesticides and fibers (Review). Molecular Medicine Reports, 2016; 14: 4467-4474. https://doi. org $/ 10.3892 / \mathrm{mmr} .2016 .5791$

8. McHale CM, Zhang L, Smith MT. Current understanding of the mechanism of benzene-induced leukemia in humans: implications for risk assessment. Carcinogenesis, 2012; 33: 240-52. https://doi. org/10.1093/carcin/bgr297

9. World Heatlh Organization T. Exposure to Benzene: A Major Public Health Concern. Available at http://www. who.int/ipcs/features/benzene.pdf.

10. Fenga C, Gangemi S, Costa C. Benzene exposure is associated with epigenetic changes (Review). Molecular Medicine Reports, 2016; 13: 3401-3405. https://doi.org/10.3892/mmr.2016.4955

11. Holeckova B, Piesova E, Sivikova K, Dianovsky J. Chromosomal aberrations in humans induced by benzene. Ann. Agric. Environ. Med., 2004; 11: 175179.

12. Bahadar H, Mostafalou S, Abdollahi M. Current understandings and perspectives on non-cancer health effects of benzene: A global concern. Toxicology and Applied Pharmacology, 2014; 276: 83-94. https://doi. org/10.1016/j.taap.2014.02.012

13. Meckenstock RU, Boll M, Mouttaki H, Koelschbach JS, Cunha Tarouco P, Weyrauch P, Dong X, Himmelberg AM. Anaerobic degradation of benzene and polycyclic aromatic hydrocarbons. Journal of Molecular Microbiology and Biotechnology, 2016; 26: 92-118. https://doi.org/10.1159/000441358

14. Hyman MR, Sansome-Smith AW, Shears JH, Wood PM. A kinetic study of benzene oxidation to phenol by whole cells of Nitrosomonas europaea and evidence for the further oxidation of phenol to hydroquinone. Archives of Microbiology, 1985; 143: 302-306. https:// doi.org/10.1007/BF00411254

15. Chang M-K, Voice TC, Criddle CS. Kinetics of competitive inhibition and cometabolism in the biodegradation of benzene, toluene, and $p$-xylene by two Pseudomonas isolates. Biotechnology and Bioengineering, 1993; 41: 1057-1065. https://doi.org/10.1002/bit.260411108

16. Shirai K. Catechol Production from Benzene through Reaction with Resting and Immobilized Cells of a Mutant Strain of Pseudomonas. Agricultural and Biological Chemistry, 1987; 51: 121-128. https://doi. org/10.1271/bbb1961.51.121

17. Mukherjee S, Bardolui N.K., Karim S, Patnaik V.V., Nandy RK, Bag PK. Isolation and characterization of a monoaromatic hydrocarbon-degrading bacterium, Pseudomonas aeruginosa from crude oil. Journal of Environmental Science and Health - Part A Toxic/ Hazardous Substances and Environmental Engineering, 2010. https://doi.org/10.1080/10934529.2010.48632 8
18. Iqbal A, Arshad M, Hashmi I, Karthikeyan R, Gentry TJ, Schwab AP. Biodegradation of phenol and benzene by endophytic bacterial strains isolated from refinery wastewater-fed Cannabis sativa. Environmental Technology (United Kingdom), 2018; 39: 1705-1714. https://doi.org/10.1080/09593330.2017.1337232

19. Sciences B, Science F, Box PO. Isolation and Molecular Identification of New Benzene Degrading Lysinibacillus Strains from Gasoline Contaminated Soil Fawzi I. Irshaid and Jacob H. Jacob., 2016; 8: 34-43. https:// doi.org/10.19026/rjees.8.3064

20. Rooney-Varga JN, Anderson RT, Fraga JL, Ringelberg David, Lovley DR. Microbial Communities Associated with Anaerobic Benzene Degradation in a PetroleumContaminated Aquifer. ; 1999: 1-3056-3063. Available at http://aem.asm.org/. Accessed August 11, 2018.

21. Coates JD, Chakraborty R, Lack JG, O'Connor SM, Cole KA, Bender KS, Achenbach LA. Anaerobic benzene oxidation coupled to nitrate reduction in pure culture by two strains of Dechloromonas. Nature, 2001; 411: 1039-1043. https://doi.org/10.1038/35082545

22. Da Silva MLB, Alvarez PJJ. Assessment of anaerobic benzene degradation potential using 16S rRNA genetargeted real-time PCR. 2006. https://doi.org/10.1111/ j.1462-2920.2005.01116.x

23. Vogt C, Kleinsteuber S, Richnow HH. Anaerobic benzene degradation by bacteria. Microbial Biotechnology, 2011; 4: 710-724. https://doi.org/10.1111/j.17517915.2011.00260.x

24. Meckenstock RU, Boll M, Mouttaki H, Koelschbach JS, Cunha Tarouco P, Weyrauch P, Dong X, Himmelberg AM. Anaerobic degradation of benzene and polycyclic aromatic hydrocarbons. Journal of Molecular Microbiology and Biotechnology, 2016; 26: 92-118. https://doi.org/10.1159/000441358

25. Smith MR. The biodegradation of aromatic hydrocarbons by bacteria. 1990; 191-206. https:// doi.org/10.1007/978-94-011-3452-1_9

26. Boone DR, Castenholz RW, Garrity GM. Bergey's manual of systematic bacteriology. Springer; 2001. https://doi.org/10.1007/978-0-387-21609-6

27. Buzon-Duran L, Capita R, Alonso-Calleja C. Antibiotic susceptibility of methicillin-resistant staphylococci (MRS) of food origin: A comparison of agar disc diffusion method and a commercially available miniaturized test. Food Microbiology, 2018; 72: 220-224. https://doi.org/10.1016/j.fm.2017.11.018

28. Kiehlbauch JA, Hannett GE, Salfinger M, Archinal W, Monserrat C, Carlyn C. Use of the National Committee for Clinical Laboratory Standards guidelines for disk diffusion susceptibility testing in New York state laboratories. Journal of Clinical Microbiology, 2000; 38: $3341-8$.

29. Sambrook J, Russell DW (David W. Molecular cloning/ : a laboratory manual). Cold Spring Harbor Laboratory Press; 2001.

30. Som A. Theoretical foundation to estimate the relative efficiencies of the Jukes-Cantor+gamma model and the Jukes-Cantor model in obtaining the correct phylogenetic tree. Gene, 2006; 385: 103-110. https:// doi.org/10.1016/j.gene.2006.03.027 
31. Saitou N, Nei M. The neighbor-joining method: a new method for reconstructing phylogenetic trees. Mol. Biol. Evol., 1987; 4: 406-425.

32. Tamura K, Nei M, Kumar S. Prospects for inferring very large phylogenies by using the neighbor-joining method. Proc. Natl. Acad. Sci. USA. 2004; 101: 1103011035. https://doi.org/10.1073/pnas.0404206101

33. Wright ES, Yilmaz LS, Noguera DR. Decipher, a search-based approach to chimera identification for $16 \mathrm{~S}$ rRNA sequences. Applied and Environmental Microbiology, 2012; 78: 717-725. https://doi. org/10.1128/AEM.06516-11

34. Mukherjee S, Bardolui NK, Karim S, Patnaik VV, Nandy RK, Bag PK. Isolation and characterization of a monoaromatic hydrocarbon-degrading bacterium, Pseudomonas aeruginosa from crude oil. Journal of Environmental Science and Health - Part A Toxic/ Hazardous Substances and Environmental Engineering, 2010; 45. https://doi.org/10.1080/10934529.2010.48 6328

35. Di E, Ferrandez A, Prieto MA, Garci L, Ferra A. Biodegradation of Aromatic Compounds by Escherichia coli Biodegradation of Aromatic Compounds by Escherichia coli. Society, 2001; 65: 523-569. https:// doi.org/10.1128/MMBR.65.4.523-569.2001

36. Jang J, Hur HG, Sadowsky MJ, Byappanahalli MN, Yan T, Ishii S. Environmental Escherichia coli: ecology and public health implications-a review. Journal of Applied Microbiology, 2017; 123: 570-581. https:// doi.org/10.1111/jam.13468

37. Boyte S, Quaife S, Horswell J, Siggins A. Survival of Escherichia coli in common garden mulches spiked with synthetic greywater. Letters in Applied Microbiology, 2017; 64: 386-391. https://doi. org/10.1111/lam.12732

38. Moretto JAS, Braz VS, Furlan JPR, Stehling EG. Plasmids associated with heavy metal resistance and herbicide degradation potential in bacterial isolates obtained from two Brazilian regions. Environmental Monitoring and Assessment. 2019; 191: 314. https:// doi.org/10.1007/s10661-019-7461-9

39. Pasumarthi R, Chandrasekaran S, Mutnuri S. Biodegradation of crude oil by Pseudomonas aeruginosa and Escherichia fergusonii isolated from the Goan coast. Marine Pollution Bulletin, 2013; 76: 276-282. https://doi.org/10.1016/j. marpolbul.2013.08.026

40. Sriram MI, Gayathiri S, Gnanaselvi U, Jenifer PS, Mohan Raj S, Gurunathan S. Novel lipopeptide biosurfactant produced by hydrocarbon degrading and heavy metal tolerant bacterium Escherichia fergusonii KLU01 as a potential tool for bioremediation. Bioresource Technology, 2011; 102: 9291-9295. https://doi. org/10.1016/j.biortech.2011.06.094

41. Maiti A, Das S, Bhattacharyya N. Bioremediation of High Molecular Weight Polycyclic Aromatic Hydrocarbons by Bacillus thuringiensis Strain NA2.; 2012. Available at www.worldsciencepublisher.org. Accessed July 29, 2018.

42. Mukherjee AK, Bordoloi NK. Biodegradation of benzene, toluene and xylene ( BTX ) in liquid culture and in soil by Bacillus subtilis and Pseudomonas aeruginosa strains and a formulated bacterial consortium. 2012; 3380-3388. https://doi.org/10.1007/s11356-0120862-8

43. Taylor P, Basak SP, Sarkar P, Pal P. Journal of Environmental Science and Health, Part A/ : Toxic / Hazardous Substances and Environmental bacteria from industrial effluent-contaminated soil and Isolation and characterization of phenol utilizing bacteria from industrial effluent-contaminated. 2014;37-41.

44. Rooney-Varga JN, Anderson RT, Fraga JL, Ringelberg David, Lovley DR. Microbial Communities Associated with Anaerobic Benzene Degradation in a PetroleumContaminated Aquifer. ; 1999: 1-3056-3063. Available at http://aem.asm.org/. Accessed August 6, 2018.

45. Jensen A-M, Finster KW, Karlson U. Degradation of carbazole, dibenzothiophene, and dibenzofuran at low temperature by Pseudomonas sp. strain C3211. Environmental Toxicology and Chemistry, 2003; 22: 730-735. https://doi.org/10.1002/etc.5620220408

46. Dou J, Ding A, Liu X, Du Y, Deng D, Wang J. Anaerobic benzene biodegradation by a pure bacterial culture of Bacillus cereus under nitrate reducing conditions. Journal of Environmental Sciences, 2010; 22: 709-715. https://doi.org/10.1016/S1001-0742(09)60167-4

47. Burlingame R, Chapman PJ. Catabolism of phenylpropionic acid and its 3-hydroxy derivative by Escherichia coli. Journal of Bacteriology, 1983; 155: 113-21. 